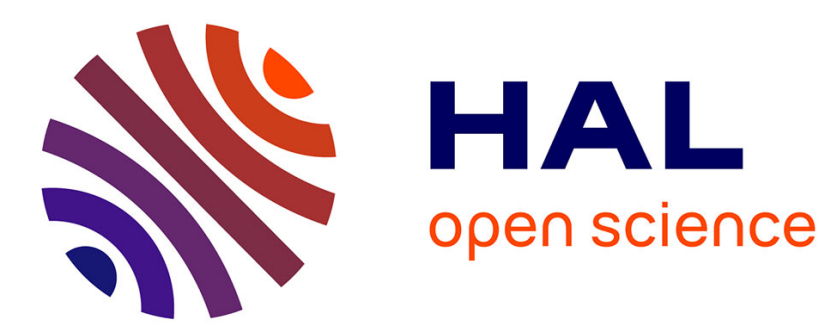

\title{
The media and public opinion on genetics and biotechnology: mirrors, windows, or walls?
}

Toby A. Ten Eyck

\section{To cite this version:}

Toby A. Ten Eyck. The media and public opinion on genetics and biotechnology: mirrors, windows, or walls?. Public Understanding of Science, 2005, 14 (3), pp.305-316. 10.1177/0963662505052888 . hal-00571064

\section{HAL Id: hal-00571064 \\ https://hal.science/hal-00571064}

Submitted on 1 Mar 2011

HAL is a multi-disciplinary open access archive for the deposit and dissemination of scientific research documents, whether they are published or not. The documents may come from teaching and research institutions in France or abroad, or from public or private research centers.
L'archive ouverte pluridisciplinaire HAL, est destinée au dépôt et à la diffusion de documents scientifiques de niveau recherche, publiés ou non, émanant des établissements d'enseignement et de recherche français ou étrangers, des laboratoires publics ou privés. 


\title{
The media and public opinion on genetics and biotechnology: mirrors, windows, or walls?
}

\author{
Toby A. Ten Eyck
}

Arguments regarding the relationship between media discourse and public opinion have raged for decades, if not centuries. Comparing media coverage of biotechnology between 1992 and 2001 in two national newspapers with national survey data collected in early 2003, an argument is made that a general one-dimensional media effect is not occurring within the US public regarding media discourse. Given the multivalent characteristics of the media and the interpretive filters used by audiences-including ignoring information-even strong slants by the presumed opinion-leading press (the New York Times and the Washington Post) do not predict public opinion on a nascent issue such as biotechnology. While some reflections do appear between the media and public opinion, closer observations show these mirrors to be ephemeral.

\section{Introduction}

Debates over biotechnology have gained a great deal of attention from researchers involved in both the natural and the social sciences, as well as from reporters and other individuals concerned with discourses in public arenas. Medical breakthroughs (e.g., Boyer, 2003) and tragedies (e.g., Pollack, 2003) have been brought to the public by the popular press, while scholars have conducted surveys of public opinion (e.g., Shanahan et al., 2001), studied public participation activities (e.g., Einsiedel et al., 2001), and critiqued the capitalistic tendencies of firms with vested interests in these issues (e.g., Kimbrell, 2002). Opinions on biotechnology range from the end of humanity to feeding the world (e.g., Nottingham, 1998), while research shows that individuals are wildly for or against genetic engineering, or have little interest in and/or knowledge about these issues. In other words, there is little agreement on the nature of the impacts of biotechnology, its discursive influences, and its impact on the social landscape. These are debates that deal with emotions, facts, figures, and vested interests. There are many sources of information with references to biotechnology, and the present study seeks to shed light on one of these sources and its influence-linkages (or the lack thereof) between the press and public opinion. This is not a search for causal processes, but an investigation into the similarities and differences between media and public representations. 
The impetus behind this undertaking is Gunther's (1992) ascertainment that it is not necessarily the press that is biased on any specific issue. While researchers, seed company representatives, farmers, and others argue that the media are driving the debates over biotechnology, there is little consensus among these actors as to where the debate is being driven, other than away from their own point(s) of view. At the same time, in the survey that provides some of the data for this study, only 55 percent of respondents said they trust the media to tell them "the truth" about biotechnology. If the media are driving the debate, but just over half of the US population says it trusts the media to tell the truth, then we must look more closely at what these two components of society are saying, and can only then posit explanations for possible influence. We may find that the public does not use the media to form opinions, that the media do not reflect the opinions of the public, or that our survey respondents were not telling the truth about their own opinions. These and other rationales could be argued as the forces behind the findings of any survey or content analysis, though it is our intention only to highlight what is being said on this issue, offer some explanations for our findings, but leave it to readers to develop their own interpretations of the ties between the media and the public.

\section{The biotechnology debate}

One of the more interesting aspects of the biotechnology debate is that it encompasses issues ranging from food and agriculture to medicine, crime, nature versus nurture, and privacy concerns, to name just a few of the more popular topics. Each issue resonates deeply with American culture. Many Americans deal with food on a daily basis; health has become a dominant issue as we strive to be forever young; medical answers are sought for many personal and social problems (Conrad, 1997); and as an individualistic society we enjoy our privacy and want it protected. The use of biotechnology and genetic engineering in these areas, though, is relatively new, meaning that little experiential knowledge and public wisdom exists. One of the confounding aspects of technological approaches to these issues is that technology has been part of some of the cultural spheres (e.g., medicine), but may not be considered natural in others (e.g., food), and in some cases technology is thought of as the cause of current crises (e.g., privacy). It becomes imperative for agents of legitimation, such as the media, courts, legislative bodies, and scientific organizations, to support or discredit efforts in these areas for members of the lay audience to make sense of how the issues are being treated and how they will affect their lives.

The legitimation of biotechnology and genetics goes beyond scientists, food, and medicine. In a study carried out by Nisbet and Lewenstein (2002), media coverage was found to both reflect and impact policy decisions. In addition, these issues have historical contexts, which should be considered. For example, the same study found that some actors were able to deflect media coverage through the structures in which they were situated. This is an extension of Ericson, Baranek, and Chan's (1989) work on news linkages, as these linkages could be used to both generate and negate stories. This may have implications for those involved in decision-making surrounding biotechnology and genetic issues as these become more controversial. Government officials who are able to deflect the media prior to any controversy may find themselves having to justify earlier (non-)decisions, putting them in a position to be a target for groups arguing that government is in bed with industry.

Scientists and government officials often enjoy access to journalists, though journalists also have a role to play in deciding which voices will be presented in the media, and how that voice is used. In addition, while people have experiential knowledge concerning various 
issues related to biotechnology, many of the technologies being developed do not resonate with their stocks of technological knowledge. In other words, there are two gaps-one with regards to biotechnology and the second with regards to technology as a component of a cultural sphere. This makes for an interesting situation, as members of the lay public hear about discoveries which may revolutionize cultural spheres for which there already exist stocks of knowledge, and these stocks of knowledge may be considered appropriate for, if not preferred over, other, novel approaches. Given the legitimative role played by scientists and government officials around issues of risk, what is said in the media about these technologies and by whom it is said may have some impact on public opinion. The objectivity principle of the press, though, may attenuate or confound the ability of a person not familiar with this issue to make a decision on whether or not to support the technology (Tuchman, 1978; Ten Eyck, 1999). The media, however, are not one-dimensional, and studies have found wide variations in how media representations are interpreted (e.g., Fiske, 1992; Hoijer, 1992; Morley, 1980). Still, researchers seek linkages, and this is the focus of the next section.

\section{The media and public opinion-are there links?}

The relationship between the media and the public has been debated for decades, if not centuries (Hardt, 1992). If we start with the work of Marcuse (1964), we begin with the idea that people are easily led astray by the images and ideals of popular culture. ${ }^{1}$ This is to say that the general public consists of individuals who are easily duped into the culture of consumerism, where their buying habits have been molded by the channels of popular culture. This line of reasoning was further supported by the work of Gerbner (e.g., Gerbner et al., 1979) and his cultivation theory. According to this perspective, people who were heavy consumers of violent television were more likely to think of the "real" world as a violent place than viewers who watched fewer of these shows. In addition, Phillips (1983) and Bollen and Phillips (1982) found correlations between highly publicized prize-fights and homicides, as well as between highly publicized suicides (even fictional ones such as a suicide in a soap opera) and the general suicide rate. All of this research points to some link - something happens on television, in the movies, or in the tabloids, and people copy it or are moved by it to consume.

Not all audience research, though, has found such a strong relationship between the depiction of action and "real" action. Dearing and Rogers (1996), for example, contend that the media do bring issues to public attention, but that people have the ability to think differently about the issues. Gamson (1992) came to much the same conclusion, arguing that, while the media do play a powerful role in constructing attitudes toward issues where little experiential knowledge exists, people will actively work around and through issues, even complex ones such as the conflicts in the Middle East. This agenda-setting approach, though, still favors a strong linkage between the media and the public. Those working within this perspective may not claim to be able to predict public opinions, but they still insist that what is in the media will be discussed in the public.

Morley (1980), on the other hand, found that some members of the public had very little interest in various issues discussed in the media, even when those issues were deemed important and truly newsworthy by experts. Individuals who felt the issues had very little impact on their lives or that they had very little power over the issues often ignored coverage. Ten Eyck (2001) found the rates of ownership of television and radio sets in a 
country were related to the number of instances of demonstrations and strikes, though the link was weaker with regards to riots. This highlights a situation in which events are treated differently, adding a layer of complexity to the influence of the media on the audience. Bauman (1992) has argued that media researchers must turn off the television once in a while and stroll through the streets of cities and towns to get a feel for what is really taking place in the public, as hyperreality is exactly that - a fictional account of the real. In fact, Gans (1993) contends that the people most affected by the media are media researchers themselves. These findings suggest that various audience members are affected differently by media content, which is confounded by an interaction-effect based on both the content of the message and the context in which it is received.

The other side of the coin is represented by a perspective that argues that what is found in the media is little more than a reflection of existing public opinion. Bourdieu (1984) has suggested that reporters feel they represent the public, so they try to find ways to report not only on issues the public will be interested in, but also on issues which could help them improve their lot in life. If this is the case, reporters are relating stories that reflect the lives (or potential lives) of their readers. Frankovic (1998) takes a more formal approach, arguing that the presentation of polling data in the media offers a quantified reflection of the public to the public. This way, audience members can compare their own opinions to those of the "masses."

In work on marketing and audience-making, authors such as Miller (1994) and Barnes and Thomson (1994) contend that the mass media are constantly modifying their programming to fit the needs and interests of the audience. The end result is one in which programs reflect the "real world" of the audiences, even when those depictions are fantastical. Lalvani (1995) found much the same situation in nineteenth-century Europe, where a fascination with the Orient and with sexuality (the "exotic other") among the population at large (especially among males) was used as a marketing tool by various companies to offer images that were already deemed exotic (and often erotic). In addition, James (1995) found that images of Western culture were used to bring down the Communist regimes of Eastern Europe and Russia, and that, once the Iron Curtain had fallen, citizens of these countries were quick to seek out and consume the cultural icons they had seen on television but never had the opportunity to experience directly.

There can be little doubt that the media play both roles. In some cases, issues are brought to the fore that have little resonance among the reading/viewing public, owing to a lack of experiential knowledge. At other times, the media report on specific issues that the public has shown an interest in, or where it has been part of the reporting process, such as in polling. In the former case, we could expect media presentations to have some effect on public opinion, as no opinions existed prior to the story being published; in the latter, opinions may hold even in light of contradictory news coverage, as values and beliefs are already set. Our interest in this paper is primarily linked to the former situation, as we would argue that biotechnology has not become a household term or event in the United States, outside of media presentations (which include such popular cultural icons as Jurassic Park). To investigate parallels or disconnects, we collected news articles on biotechnology and other issues related to genetics from two leading newspapers (the New York Times and the Washington Post) between 1992 and 2001, and public opinion data in early 2003. We do not purport to know the exact lag time-if one exists at all — between a news event and swings in public opinion, as evidence has shown that it varies depending on the issue. ${ }^{2}$ Instead, we believe that if people in the United States do know about biotechnology, it will be due, at least in part, to media exposure. 


\section{Data and methods}

\section{The newspapers}

This content analysis was part of a larger research program involving 14 European countries, Canada, and the United States (Gaskell and Bauer, 2001). The group responsible for this project had developed sampling and coding schemes which were followed for the present study, with some modifications to take into account nuances within the United States. Researchers from each country were asked to develop intensity figures concerning articles relating to genetics and biotechnology in "opinion-leading" newspapers, and then to choose a random set of articles from this list to analyze. We chose the New York Times and the Washington Post as the opinion leaders in the United States. The larger project called for looking at news coverage since the early 1970s (1971-2001 for the New York Times and 1977-2001 for the Washington Post), though it was decided that current public opinion may have been generated around the release in 1992 of Jurassic Park-The Movie, which has become one of the top movies for box office sales around the world. Given this, we know that many people were exposed to this movie and its rendition of biotechnology (the resurrection of dinosaurs), and that both the New York Times and the Washington Post covered the movie with reviews, commentary, and regular news articles. In addition, relative to changes in prior years, coverage intensity jumped from 746 articles in 1991 to 883 in 1992. The last year of coverage under study - 2001—was the last full year available when the content analysis was undertaken (in total 1,921 articles appeared in 2001, the highest of any of the years in this period). A precursory study of news articles in 2002 and just prior to the opinion poll being conducted in early 2003 did not uncover any changes in how biotechnology and genetics have been covered.

Newspaper articles that contained the words genetic!, biotech!, genome, and DNA (the "!" being a wildcard character) were logged onto calendars to generate the intensity trends for each year under investigation. Given these figures, considerations for comparability with the other countries, and local time and financial resources, 100 articles from each newspaper for each year between 1992 and 2001 were randomly selected and coded. The selection method, agreed upon by the larger project group, consisted of rolling a die, choosing the article from the calendar that matched the die (starting with 1 January of each year), and then choosing articles based on the number needed to code divided by the total number of articles published in each newspaper for each year. For example, if there were 1,000 articles in the New York Times in 1995, we would choose every tenth article to code. If the die rolled a two, we would code the second article that appeared in 1995, and then the twelfth, the twenty-second, and so on. A total of 2,000 articles were selected in this manner and coded. This analytical model is consistent with Stempel's (1989) description of content analysis.

A majority of the articles were coded by two individuals. To generate inter-coder reliability, the same articles were coded until the set of variables (48 in all) matched 80 percent of the time between the coders (this took about ten articles). ${ }^{3}$ At that point, coders worked independently unless major questions were raised. The variable list was borrowed from work by Durant et al. (1998), which, in turn, was based heavily on studies of nuclear power conducted by Gamson (1992) and Gamson and Modigliani (1989).

While every content analysis should carry some kind of caveat, and the current study is no exception, we do feel comfortable in stating that this study does represent a broad overview of the coverage of genetic-related issues as carried by the elite press in the United States. As mentioned, the New York Times and the Washington Post are considered two of the most important newspapers for national policymakers (Gans, 1979; see also Gitlin, 1980). In 
addition, while other coding schemes could have been used (e.g., only using front page articles, or using articles that only discussed the watershed events mentioned above), the articles chosen and coded do describe to some degree what was available to the US public for a ten-year time span over a broad range of issues.

\section{The public}

A nationwide survey of adults in the United States was conducted between December 2002 and February 2003 by the Population Data Center at Louisiana State University. Using a random dialing procedure and weighting for time zones in the US (Pacific, Mountain, Central, and Eastern), 855 individuals completed the survey, while an additional 206 completed at least part of the survey. The 855 respondents who completed the survey account for a cooperation rate of 32 percent for the known eligibles (2,694 known eligibles). ${ }^{4}$ According to Frey and Oishi (1995), analyses of data from telephone surveys with response rates lower than 70 percent should be considered with some concern. Given the rise in telemarketing and other ways of using the telephone for business and research purposes (including the length of this survey instrument), it is not surprising that response rates have been falling. So, while a number of reasons could be given for this low cooperation rate that have nothing to do with biotechnology, the fact that a majority of potential respondents were not interested in participating in the survey may be the first indication that the relationship between the media and the public is a window; a window which only the media are looking though. Intensity figures show that media attention to genetics and biotechnology has been rising over the past ten years (Ten Eyck et al., 2001), yet randomly chosen individuals in the US seem uninterested in giving their opinion about the topic.

As was the case with the media analysis procedures, the survey instrument was developed in cooperation with researchers from Canada and Europe. ${ }^{5}$ Questions ranged from concerns with various technologies (e.g., solar energy, space exploration, the Internet, and nuclear power) to knowledge about genetics (e.g., is it true or false that genetically engineered tomatoes have genes while ordinary ones do not?), to trust in various institutions connected with the debates over biotechnology. In addition, an open-ended question concerning what is meant when someone says he/she has an ethical concern with biotechnology was added to the US survey. The average time to complete the survey was approximately 30 minutes.

\section{Analysis}

As mentioned, the correlation between the amount of coverage, on the one hand, and the interest in taking part in the survey, on the other, seems weak, if non-existent. At the same time, people who had heard about biotechnology did so through the media as compared to other potential sources of information (see Table 1). Of the 855 individuals polled, 668 (78 percent) said they had heard something about biotechnology over the past 30 days, mostly through the television (58 percent of these respondents). The lowest ranking category was family and friends ( 12 percent), though 65 percent of respondents said they had talked about biotechnology with others at some point in the past. It is also interesting to note that new technologies, such as the Internet, seem to be more frequently used than some traditional ones, at least on this issue.

Table 2 shows the relationships (or lack thereof) between being a main actor in the 
Table 1. Sources of information on biotechnology and participation in the debate about it

\begin{tabular}{lr}
\hline $\begin{array}{l}\text { Have you heard anything about } \\
\text { biotechnology lately? }(N=855)\end{array}$ & $\begin{array}{r}\text { Yes } 78.1 \% \\
\text { No } 21.4 \%\end{array}$ \\
& Don't know $0.5 \%$ \\
Heard about it from $\ldots(N=668)$ & $58.1 \%$ \\
Television & $49.3 \%$ \\
Newspapers & $27.7 \%$ \\
Internet & $24.3 \%$ \\
Magazines & $18.6 \%$ \\
Radio & $11.7 \%$ \\
Family and friends & $6.9 \%$ \\
Other & Yes $65.4 \%$ \\
Have you ever discussed biotechnology & No $34.5 \%$ \\
with others? $(N=855)$ & Don't know $0.1 \%$ \\
\hline
\end{tabular}

news and how survey respondents felt about these actors doing a good job for society and trusting them to tell the truth about biotechnology. The most frequently cited main actor in the press was industry, though they ranked eighth on doing a good job for society with regards to biotechnology, and eleventh on the trust issue. University scientists ranked second in frequency of media appearance, and first on both doing a good job and trust. National government spokespersons rated third in frequency of appearance, and tenth for both of the survey questions.

The idea that frequency of appearance may translate into acceptance and trust is tempered by the nature of the appearance. A cross tabulation of sources by slant of the article shows that scientists are much more likely to be linked to positive evaluations than

Table 2. Sources and trust

\begin{tabular}{|c|c|c|c|}
\hline Source & $\begin{array}{l}\text { Number of articles in } \\
\text { which category was } \\
\text { main actor }(N= \\
2000)\end{array}$ & $\begin{array}{l}\text { Doing a good job for } \\
\text { society with regards } \\
\text { to biotechnology } \\
\text { (\% strongly agree or } \\
\text { agree) }(N=855)\end{array}$ & $\begin{array}{l}\text { Trust to tell the truth } \\
\text { about biotechnology } \\
\text { (\% strongly agree or } \\
\text { agree) }(N=855)\end{array}$ \\
\hline Industry & 450 & $66.2 \%$ & $44.4 \%$ \\
\hline University scientists & 354 & $85.4 \%$ & $85.3 \%$ \\
\hline National government & 311 & $54.5 \%$ & $44.8 \%$ \\
\hline Industry scientists & 80 & $80.8 \%$ & - \\
\hline Media/media opinion & 49 & $67.3 \%$ & $54.5 \%$ \\
\hline Medical doctors & 28 & $73.1 \%$ & $79.3 \%$ \\
\hline International organizations & 21 & - & $51.6 \%$ \\
\hline Farmers & 21 & $71.3 \%$ & $64.8 \%$ \\
\hline Scientific organizations & 14 & - & $82.9 \%$ \\
\hline Consumer organizations & 11 & $67.5 \%$ & $68.3 \%$ \\
\hline Patient organizations & 8 & $68.1 \%$ & - \\
\hline Religious organizations & 7 & - & $38.2 \%$ \\
\hline Environmental groups & 4 & $47.7 \%$ & $64.0 \%$ \\
\hline Political parties & 1 & - & $20.7 \%$ \\
\hline Stores & 1 & $58.7 \%$ & - \\
\hline Animal welfare & - & - & $50.2 \%$ \\
\hline
\end{tabular}


either government or industry is, while government officials are more likely to be linked to very critical articles. We assume that much more is involved in developing opinions about these groups, but if critical presentations are tied to distrust, then the media are setting public opinion against the government and industry (though industry scientists are thought to be doing a good job for society).

A study by Ten Eyck and Williment (2003) also found a difference in how various issues related to biotechnology and genetics have been treated. According to this study, news reports have treated agricultural biotechnology in a much less flattering way than medical biotechnology. Table 3 shows public opinions on five different applications of biotechnology - two food and crop and three medical ones. The findings are mixed. The use of genetic testing to detect inherited diseases enjoys the highest support with 86 percent of respondents thinking such an application would be useful, while 42 percent think it would be risky. The lowest support is given to xenotransplantation (using animals as human organ growers and donors), with 67 percent thinking it would be useful and 54 percent thinking it would be risky. The highest level of risk is attributed to the cloning of human cells to replace diseased or injured cells (58 percent), though this application also scores second behind genetic testing in usefulness (79 percent). Respondents give both food and crop applications high scores on usefulness (71 percent on using biotechnology in foods and 75 percent on using biotechnology to decrease pesticide use), though the former also received the second highest mark on risk (55 percent).

If the link between media and audience opinions is considered to be causal, it is at this point that such an assumption of causality comes under fire. As noted earlier, media reports of medical applications (at least in the national press) have been, on average, more positive than portrayals of food and crops, and, while two of the medical applications were thought to be more useful than the food and crop applications, the differences were not immense. One could argue that many more "mass media" discourses exist than the national press; this is true, but then those who contend so would need to show which discourses are influencing public opinion. One indication that people do have the ability to interpret information in their own way comes from another set of questions asked of respondents. For both the production of food and the cloning of human cells, respondents were asked what was most important in their decision about whether the application should be encouraged. In both

Table 3. Opinions on various applications of biotechnology

\begin{tabular}{lll}
\hline & $\begin{array}{l}\text { Utility } \\
\text { (\% definitely } \\
\text { agree or tend } \\
\text { to agree) }\end{array}$ & $\begin{array}{l}\text { Risk } \\
\text { (\% definitely } \\
\text { agree or tend } \\
\text { to agree) }\end{array}$ \\
\hline $\begin{array}{l}\text { Use modern biotechnology in the production of foods, for } \\
\text { example to make them higher in protein, keep longer, or improve } \\
\text { the taste }\end{array}$ & $71.0 \%$ & $55.0 \%$ \\
$\begin{array}{l}\text { Taking genes from plant species and transferring them into crops } \\
\text { to decrease the use of pesticides and increase food output }\end{array}$ & $75.3 \%$ & $46.7 \%$ \\
$\begin{array}{l}\text { Using genetic testing to detect diseases we might have inherited } \\
\text { from our parents such as cystic fibrosis }\end{array}$ & $86.2 \%$ & $41.9 \%$ \\
$\begin{array}{l}\text { Introducing human genes into animals to produce organs for } \\
\text { human transplants, such as into pigs for human heart transplants } \\
\text { Cloning human cells or tissues to replace a patient's diseased } \\
\text { cells that are not functioning properly, for example in }\end{array}$ & $67.0 \%$ & $53.8 \%$ \\
\begin{tabular}{l} 
Parkinson's disease \\
\hline
\end{tabular} & & \\
\hline
\end{tabular}


cases, usefulness was most important (51 percent for food and 52 percent for the cloning of cells), but risk was more important with respect to food (33 percent versus 21 percent), while moral concerns were less so (11 percent versus 23 percent). The idea that genetically modified food would be considered more risky than an invasive medical procedure such as the cloning and use of human cells highlights the active interpretive processes of the audience. This is especially true given the highly publicized deaths connected to medical experiments with genetic engineering, while no one seems to have died from eating genetically modified foods. The concern with the morality of cloning human cells does echo that of media presentations on this issue, though the number of people concerned with the morality issue pales in comparison with that for usefulness.

\section{Conclusions}

This article began with an interest in elucidating the similarities and differences between mass media and public opinion. The topic of biotechnology/genetic engineering was chosen due to the (assumed) lack of experiential knowledge available at the lay level. A content analysis of the New York Times and the Washington Post was conducted for all years between 1992 and 2001 and compared to a national opinion poll conducted in the early part of 2003. If the public were being led by the media, we would expect to find general trends in the opinion polls, which would echo those of the content analysis. While in some cases this seemed to be the case, it was not the rule. First, while attention to biotechnology and genetic engineering has been increasing among reporters, a lack of interest found among potential survey respondents would indicate a wall between these two groups. Among those who did take part in the survey, more people said they had heard about biotechnology through various media sources (e.g., newspapers, television, the Internet, radio) than from family and friends, offering the possibility of a stronger link between opinions and media coverage. Their opinions toward various sources involved in the coverage of biotechnology did not reflect the amount of coverage given to these sources, though the type of coverage (critical versus positive) was more closely tied to opinions.

Opinions on food and agricultural applications versus those of medical applications closely reflect media coverage except in the case of xenotransplantation. It could be argued, though, that discussions of using animals as human organ growers and donors flies in the face of values held in a society which has embraced animal welfare rights, though it continues to consume large quantities of meat (Spedding, 2000). In other words, the issue of using animals as "medical farms" draws on enough experiential knowledge, public wisdom, or conflicting media discourse concerning animals that any medical progress related to it is overshadowed by affection for the animals. Any media coverage that frames these techniques as progress will be annulled by these held values.

The role of the media, as argued here, runs the gamut of leading, reflecting, and ignoring the public. Given the above findings, we cannot argue for a causal relationship between media content and public opinion in some broad, non-critical way. Neither can we argue that no such relationship exists. An understanding of complex technological issues, whether or not that understanding is "correct," does rely heavily on the media, even if only in terms of information diffusion. Most people we surveyed are not returning to school to learn more about biotechnology and genetic engineering, nor do we assume they are carrying out genetic experiments at home (at least not the kinds discussed here). More work on robust and complex theories of media influence (and, in turn, influence on the media) are 
being developed (e.g., Eveland and Dunwoody, 2002; Fiske, 1992), and work in this area must continue.

\section{Acknowledgements}

The author would like to thank Melissa Williment for her work on coding many of the newspaper articles, and the National Food Safety and Toxicology Center for supporting her graduate studies. The public opinion survey was sponsored by the National Science Foundation (NSF) (SES award no. 0115380), though opinions stated in this article do not necessarily reflect those of the NSF. The author would also like to thank members of the "Life Sciences in European Society" project, led by George Gaskell, for their diligence in developing the survey instrument and media codebook.

\section{Notes}

1 According to Couch (1990), state governments have long tried to control media outlets, as they understood the power of mass messaging in its many guises.

2 The "evidence" here is anecdotal. For example, after a story appeared in the US press concerning the use of Alar on apples, the sale of apples almost instantly dropped off in US grocery stores. At the same time, once the story was shown to be fraudulent, apple sales rebounded, but much more slowly.

3 Inter-coder reliability and media studies seem to have become contentious issues (e.g., Denzin and Lincoln, 1998: 186; Kincheloe and McLaren, 1998: 287-8; Shoemaker and Reese, 1996). This is not surprising, given the findings of Garfinkel's (1967: 186-207) work on coding medical records, of studies on the multivalence of the media (e.g., Gamson et al., 1992; Kellner, 1990), and of research on the interpretive processes of audiences (e.g., Fiske, 1992; Hoijer, 1992; Morley, 1980). It becomes a question of what is being measured when coders are expected to agree on the content of a document. In fact, we began the content analysis with three coders, but found that one was coding everything as having an economic frame (this person had strong ties to a scientist studying biotechnology). By nullifying that perspective, have we lost a portion of the audience? It is important to have consistency among coders, as one of the cornerstones of contemporary scientific practices is to be able to present work that can be replicated. At the same time, those interested in studying the media need to give more attention to finding ways to study its content that reflect the diversity of both journalistic and audience practices.

4 This response rate takes into account those individuals who are known to have been eligible to participate in the study, but refused. Telephone numbers that were disconnected, did not actually exist or refused to give any information were not used to calculate the response rate. When these numbers are taken into account, our response rate is just over 13 percent, and reports from the organization conducting the survey-the Louisiana Population Data Center-show that many more people hung up before the survey even began.

5 Some of the wording of the questions differed between countries owing to translation issues. In addition, while both the US and Canadian surveys were conducted by telephone, the European survey was part of the Eurobarometer, which is conducted face-to-face.

\section{References}

Barnes, B.E. and Thomson, L.M. (1994) "Power to the People (Meter): Audience Measurement Technology and Media Specialization," in J.S. Ettema and D.C. Whitney (eds) Audiencemaking, pp. 75-94. Thousand Oaks, CA: SAGE.

Bauman, Z. (1992) Intimations of Postmodernity. New York: Routledge.

Bollen, K.A. and Phillips, D.P. (1982) "Imitative Suicides: A National Study of the Effects of Television News Stories," American Sociological Review 47: 802-9.

Bourdieu, P. (1984) Distinction. Translated by Richard Nice. Cambridge, MA: Harvard University Press.

Boyer, J. (2003) "Ordway Putting Pieces Together: Top Talent Joins New Venture to Explore Biotechnology Frontiers," The Times Union 6 June, p. E:1.

Conrad, P., ed. (1997) The Sociology of Health and Illness (5th edn). New York: St. Martin's Press.

Couch, C.J. (1990) "Mass Communication and State Structures," The Social Science Journal 27: 111-28.

Dearing, J. and Rogers, E.M. (1996) Agenda-Setting. Thousand Oaks, CA: SAGE.

Denzin, N.K. and Lincoln, Y.S., eds (1998) The Landscape of Qualitative Research. Thousand Oaks, CA: SAGE. 
Durant, J., Bauer, M.W. and Gaskell, G., eds (1998) Biotechnology in the Public Sphere. London: Science Museum.

Einsiedel, E., Jelsøe, E. and Breck, T. (2001) "Publics at the Technology Table: The Australian, Canadian and Danish Consensus Conferences," Public Understanding of Science 10: 83-98.

Ericson, R.V., Baranek, P.M. and Chan, J.B.L. (1989) Negotiating Control. Toronto: University of Toronto Press.

Eveland, W.P., Jr. and Dunwoody, S. (2002) “An Investigation of Elaboration and Selective Scanning as Mediators of Learning from the Web Versus Print," Journal of Broadcasting and Electronic Media 46: 34-53.

Fiske, J. (1992) “Audiencing: A Cultural Studies Approach to Watching Television,” Poetics 21: 345-359.

Frankovic, K.A. (1998) "Public Opinion and Polling," in D.A. Graber, D. McQuail and P. Norris (eds) The Politics of News, pp. 150-70. Washington, DC: Congressional Quarterly Press.

Frey, J.H. and Mertens Oishi, S. (1995) How to Conduct Interviews by Telephone and in Person. Thousand Oaks, CA: SAGE.

Gamson, W.A. (1992) Talking Politics. New York: Cambridge University Press.

Gamson, W.A. and Modigliani, A. (1989) "Media Discourse and Public Opinion on Nuclear Power: A Constructionist Approach," American Journal of Sociology 95: 1-37.

Gamson, W.A., Croteau, D., Hoynes, W. and Sasson, T. (1992) "Media Images and the Social Construction of Reality," Annual Review of Sociology 18: 373-93.

Gans, H.J. (1979) Deciding What's News. New York: Vintage.

Gans, H.J. (1993) "Reopening the Black Box: Toward a Limited Effects Theory," Journal of Communication 43: 29-35.

Garfinkel, H. (1967) Studies in Ethnomethodology. Englewood Cliffs, NJ: Prentice-Hall.

Gaskell, G. and Bauer, M.W., eds (2001) Biotechnology, 1996-2000. London: Science Museum.

Gerbner, G., Gross, L., Signorelli, N. and Morgan, M. (1979) "The Demonstration of Power: Violence Profile No. 10," Journal of Communication 29: 177-96.

Gitlin, T. (1980) The Whole World is Watching. Berkeley, CA: University of California Press.

Gunther, A.C. (1992) "Biased Press or Biased Public? Attitudes toward Media Coverage of Social Groups," Public Opinion Quarterly 56: 147-67.

Hardt, H. (1992) Critical Communication Studies. New York: Routledge.

Hoijer, B. (1992) "Reception of Television Narration as a Socio-cognitive Process: A Schema-theoretical Outline," Poetics 21: 283-304.

James, B. (1995) "Learning to Consume," Critical Studies in Mass Communication 12: 287-305.

Kellner, D. (1990) Television and the Crisis of Democracy. Boulder, CO: Westview Press.

Kimbrell, A., ed. (2002) Fatal Harvest. Washington, DC: Island Press.

Kincheloe, J.L. and McLaren, P.L. (1998) "Rethinking Critical Theory and Qualitative Research," in N.K. Denzin and Y.S. Lincoln (eds) The Landscape of Qualitative Research, pp. 260-99. Thousand Oaks, CA: SAGE.

Lalvani, S. (1995) "Consuming the Exotic Other," Critical Studies in Mass Communication 12: 263-86.

Marcuse, H. (1964) One Dimensional Man. Boston, MA: Beacon.

Miller, P.V. (1994) "Made-to-Order and Standardized Audiences: Forms of Reality in Audience Measurement," in J.S. Ettema and D.C. Whitney (eds) Audiencemaking, pp. 57-74. Thousand Oaks, CA: SAGE.

Morley, D. (1980) The "Nationwide" Audience. London: British Film Institute.

Nisbet, M.C. and Lewenstein, B.V. (2002) "Biotechnology and the American Media: The Policy Process and the Elite Press, 1970 to 1999," Science Communication 24: 359-91.

Nottingham, S. (1998) Eat Your Genes. New York: Zed Books.

Phillips, D.P. (1983) “The Impact of Mass Media Violence on U.S. Homicides,” American Sociological Review 48: $560-8$.

Pollack, A. (2003) "Cancer Risk Exceeds Outlook in Gene Therapy, Study Finds," New York Times 13 June, p. A:29.

Shanahan, J., Scheufele, D. and Lee, E. (2001) "The Polls-Trends: Attitudes about Agricultural Biotechnology and Genetically Modified Organisms,” Public Opinion Quarterly 65: 267-81.

Shoemaker, P.J. and Reese, S.D. (1996) Mediating the Message. White Plains, NY: Longman.

Spedding, C.R.W. (2000) Animal Welfare. London: Earthscan.

Stempel, G.H., III (1989) "Content Analysis," in G.H. Stempel III and B.H. Westley (eds) Research Methods in Mass Communication (2nd edn), pp. 124-136. Englewood Cliffs, NJ: Prentice Hall.

Ten Eyck, T.A. (1999) "Shaping a Food Safety Debate: Control Efforts of Reporters and Sources in the Food Irradiation Controversy," Science Communication 20: 426-47.

Ten Eyck, T.A. (2001) "Does Information Matter? A Research Note on Information Technologies and Political Protest," The Social Science Journal 38: 147-60. 
Ten Eyck, T.A., Thompson, P.B. and Priest, S.H. (2001) "Biotechnology in the United States: Mad or Moral Science?," in G. Gaskell and M.W. Bauer (eds) Biotechnology, 1996-2000, pp. 307-18. London, UK: Science Museum.

Ten Eyck, T.A. and Williment, M. (2003) "The National Media and Things Genetic: Coverage in The New York Times (1971-2000) and The Washington Post (1977-2000)," Science Communication 25: 129-52.

Tuchman, G. (1978) Making News. New York: The Free Press.

\section{Author}

Toby A. Ten Eyck is currently an Assistant Professor in the Department of Sociology and National Food Safety and Toxicology Center at Michigan State University. His work focuses on media representations and public opinion of food and culture, including risks and opportunities embedded in various cultural resources. Correspondence: Department of Sociology, 316 Berkey Hall and National Food Safely and Toxicology Center, Michigan State University, East Lansing, MI 48824-1111, USA; email: toby.teneyck@ssc.msu.edu 